Proxy Warriors 



\section{Proxy Warriors}

\section{THE RISE AND FALL OF STATE-SPONSORED MILITIAS}

Ariel I. Ahram 
Stanford University Press

Stanford, California

(C) 2011 by the Board of Trustees of the Leland Stanford Junior University. All rights reserved.

No part of this book may be reproduced or transmitted in any form or by any means, electronic or mechanical, including photocopying and recording, or in any information storage or retrieval system without the prior written permission of Stanford University Press.

Printed in the United States of America on acid-free, archival-quality paper

Library of Congress Cataloging-in-Publication Data

Ahram, Ariel I. (Ariel Ira)

Proxy warriors : the rise and fall of state-sponsored militias / Ariel I. Ahram.

p. $\mathrm{cm}$.

Includes bibliographical references and index.

ISBN 978-0-8047-7358-4 (cloth : alk. paper) - ISBN 978-0-8047-7359-1 (pbk. : alk. paper)

1. Developing countries-Militia. 2. Paramilitary forces-Developing countries.

3. Developing countries-History, Military. I. Title.

UA13.A35 2011

$355.3^{\prime} 5-\mathrm{dc} 22$

2010023018

Special discounts for bulk quantities of Stanford Security Studies are available to corporations, professional associations, and other organizations. For details and discount information, contact the special sales department of Stanford University Press. Tel: (650) 736-1782, Fax: (650) $736-1784$

Typeset by Thompson Type in 10/14 Minion 